\title{
Проблема безпеки фармакотерапії афективних розладів: нові можливості
}

\author{
С.Г. Бурчинський \\ Державна установа «Інститут геронтології імені Д.Ф. Чеботарьова НАМН України», Київ, Україна
}

\begin{abstract}
Анотація. У статті розглянуто проблему пошуку ефективної фармакотерапії афективних і, в першу чергу, депресивних розладів. На сьогодні, незважаючи на широкий вибір препаратів антидепресантів і тимостабілізаторів різних поколінь і з різним типом дії, ефективність усіх стратегій терапії депресії часто залишається незадовільною. Зазначено, що характеристики безпеки $є$ провідним фактором широкого впровадження препарату в клінічну практику. Оцінено ризики розвитку побічних ефектів основних груп конвенційних антидепресантів (трициклічні антидепресанти, селективні інгібітори зворотного захоплення серотоніну, інгібітори зворотного захоплення серотоніну та норадреналіну), зокрема вплив на серцево-судинну систему, метаболічні процеси, сексуальну функцію, когнітивні функції, сон. Зазначено доцільність включення в повсякденну практику інноваційних засобів з антидепресивними і тимостабілізувальними властивостями, що дозволяє на тлі збереження ефективності терапії афективних розладів істотно підвищити безпеку лікування відповідно до сучасних світових стандартів.
\end{abstract}

Ключові слова: афективні розлади, депресія, фармакотерапія, Депріліум ${ }^{\circledast}$.

\section{Актуальність проблеми}

Проблема ефективної фармакотерапії афективних і, в першу чергу, депресивних розладів сьогодні $\epsilon$ однією з провідних і багато в чому невирішених проблем клінічної фармакології та медицини в цілому. Стрімке зростання кількості депресивних розладів у населення розвинених країн, вихід їх за останні десятиліття далеко за межі психіатрії та «включення» у сферу повсякденної діяльності неврологів, кардіологів, гастроентерологів, лікарів первинної медичної ланки, сімейних лікарів - все це висуває на перший план розробку стратегії і тактики лікування депресій різного генезу та вибір відповідних інструментів фармакотерапії [1-4].

Тут особливо слід виділити безпрецедентне збільшення кількості всіх видів психоемоційних розладів і, насамперед, депресії у пацієнтів після перенесеного COVID-19 [5-7]. Так, порівняно 3 частотою виявлення депресії в глобальній популяції у 2017 р., що становить $3,44 \%$, аналогічна оцінка, за даними великого метааналізу даних, отриманих з різних країн, у 2020 р. становить у середньому $25 \%$, тобто цей показник за рік пандемії підвищився в 7 разів [8]. Усе це ще більше актуалізувало пошук нових можливостей ефективної та безпечної фармакотерапії афективних розладів.

На цьому фоні досить парадоксальною вбачається та обставина, що, незважаючи на широкий вибір препаратів антидепресантів і тимостабілізаторів різних поколінь і з різним типом дії, ефективність усіх стратегій терапії депресії (купірування гострого епізоду, стабілізувальна і підтримувальна терапія) часто залишається незадовільною. Поряд з об'єктивними причинами (збільшення фармакорезистентних варіантів клінічного перебігу депресії), велику, а нерідко і визначальну роль у цьому відіграють і суб'єктивні фактори, зокрема:

- відсутність достатніх знань, особливо у лікарів - не психіатрів, про особливості механізму дії, клініко-фармакологічні ефекти, титрування дози, побічну дію тощо різних антидепресантів та, як результат, призначення неадекватного препарату та/або реалізація неадекватної тактики лікування;

- недостатній облік анамнезу та особливостей поєднаної фармакотерапії іншими лікарськими засобами, що в багатьох випадках чинить вирішальний вплив на ефективність та безпеку лікування, а також на прогноз захворювання;

- незадовільні характеристики безпеки більшості сучасних антидепресантів, особливо в умовах тривалого застосування в загальномедичній практиці.

Відомо, що сьогодні характеристики безпеки $\epsilon$ провідним фактором широкого впровадження препарату в клінічну практи- ку, визначаючи не тільки поняття «побічна дія», але і як основа таких критеріїв, як «широта дозового діапазону» $\mathrm{i}$ «мінімальний потенціал міжлікарської взаємодії». Загалом безпека фармакотерапії у конкретного пацієнта визначається цілою низкою факторів:

- властивостями самого препарату викликати ті чи інші побічні ефекти;

- індивідуальною непереносимістю препарату;

- наявністю супутньої патології (фактор коморбідності);

- віком пацієнта (зміною фармакодинаміки та фармакокінетики при старінні);

- поєднаним застосуванням різних препаратів в умовах комбінованої терапії (фактор поліпрагмазії).

Таким чином, усі критерії безпеки можна розділити на дві групи:

1) об'єктивні (пов'язані з особливостями конкретного препарату);

2) суб'єктивні (пов'язані з особливостями фармакотерапії у конкретного пацієнта).

I якщо суб'єктивні критерії визначаються суто індивідуальними характеристиками пацієнта, то об'єктивні критерії поняття «безпека» в клінічній фармакології $\epsilon$ більш формалізованими. У клінічних випробуваннях, виконаних у сучасному форматі, до них, перш за все, слід віднести:

- відсутність або мінімальну вираженість побічних ефектів;

- відсутність серйозних побічних ефектів.

Не менш значущими характеристиками в даному випадку $\epsilon \mathrm{i}$ такі критерії, як: а) відсутність у препарату активних метаболітів і б) відсутність перехресної лікарської взаємодії з найчастіше застосовуваними препаратами нейро- і соматотропного типу дії в рамках поліпрагмазії, практично неминучої в терапії афективних розладів (коморбідність, вік пацієнта тощо). Тому цілком природним $€$ прагнення практичних лікарів у всьому світі до застосування максимально безпечних груп лікарських засобів та їх окремих представників, нерідко навіть ціною певного зниження ефективності лікування.

У результаті проблема безпеки нейро- і психофармакотерапії постала на перший план як для фармакологів, так і для клініцистів, і змусила звернути серйозну увагу на можливі ризики при призначенні засобів даного типу дії і, перш за все, антидепресантів.

Спробуємо оцінити ризики розвитку побічних ефектів основних груп конвенційних антидепресантів (трициклічні антидепресанти (ТЦА), селективні інгібітори зворотного захоплення серотоніну (CI33C), інгібітори зворотного захоплення серотоніну та норадреналіну $(\mathrm{I33CH})$, найбільш актуальні для загальномедичної практики. 


\section{Вплив на серцево-судинну систему}

Одним з найбільш реальних ускладнень при прийомі антидепресантів, зокрема ТЦА (амітриптилін, іміпрамін, кломіпрамін), $є$ розвиток різних порушень ритму серця. Наприклад прояви різних типів шлуночкових аритмій можуть визначатися як безпосередня кардіотоксична дія цих препаратів (за рахунок збільшення інтервалу Q-T і наявності у ТЦА виражених холінолітичних ефектів). У результаті підвищується клінічно значущий ризик раптової смерті, особливо на початку курсового прийому (у 1-й місяць) цих засобів. Аналогічний ризик, особливо для пацієнтів із кардіологічною патологією, відзначається при застосуванні класичного представника I33CH - венлафаксину у високих терапевтичних дозах [9-11].

Широко застосовувані в клінічній практиці препарати СІ33С також не позбавлені ризиків побічних ефектів з боку судинної системи. Зокрема клінічно значущим може бути підвищення ризику кровотеч (за рахунок зменшення здатності агрегації тромбоцитів у результаті інгібування в них зворотного захоплення серотоніну) і особливо - інтрацеребральних геморагій у паці$\epsilon$ ттів, які раніше перенесли геморагічний інсульт [12], що змушує по-новому поглянути на проблему безпеки терапії препаратами цієї групи.

Також слід зазначити, що, з одного боку, підвищення артеріального тиску, з іншого - ортостатична гіпотензія $\epsilon$ найчастішими ускладненнями при лікуванні венлафаксином (особливо на початковому етапі терапії) $[13,14]$.

Нарешті, вельми часто при прийомі ТЦА, насамперед амітриптиліну, відзначаються підвищення частоти серцевих скорочень та виражена ортостатична гіпотензія [9].

У результаті практично всі широко застосовувані сьогодні конвенційні антидепресанти мають більш або менш виражений потенціал розвитку побічних ефектів з боку серцево-судинної системи, що істотно обмежує їх терапевтичні можливості, особливо у пацієнтів з коморбідною кардіо- і церебральною патологією й осіб літнього та старечого віку.

\section{Вплив на метаболічні процеси}

Одним із найбільш характерних побічних ефектів при лікуванні антидепресантами з групи СІ33С $є$ збільшення маси тіла, особливо типове для пароксетину, циталопраму та есциталопраму, а також розвиток гіперхолестеринемії та підвищення рівня ліпопротеїдів низької щільності $[9,15]$. Застосування цих препаратів може розглядатися як фактор, що промотує розвиток метаболічного синдрому. У поєднанні з ризиком підвищення рівня глюкози в крові (особливо для пароксетину і флувоксаміну при тривалому застосуванні) [16] слід визнати, що терапія рядом популярних препаратів групи $\mathrm{Cl} 33 \mathrm{C}$ несе значні ризики для пацієнтів з наявністю метаболічного синдрому або схильністю до нього, цукровим діабетом 2-го типу і атеросклерозом, тобто дуже великої популяції пацієнтів із афективними розладами.

Аналогічно, суттєве збільшення маси тіла відзначається і при прийомі препаратів групи ТЦА (амітриптилін) [9]. В якості механізмів розвитку зазначених ускладнень слід згадати можливість активації препаратами антидепресантів біосинтезу прозапальних цитокінів під впливом підвищення концентрації внутрішньоклітинного серотоніну, а також (для ТЦА) вплив на 5-НТ2Срецептори, відповідальні за харчову поведінку та підвищення апетиту [17]. Загалом метаболічні ефекти найбільш широко застосовуваних антидепресантів обов'язково повинні враховуватися при їх призначенні в клінічній практиці.

\section{Сексуальна дисфункція}

Одним із найчастіших ускладнень при лікуванні препаратами CI33C $€$ порушення з боку сексуальної сфери $[18,19]$, що $\epsilon$ основною причиною відмови від подальшого лікування даними засобами. Зазначені порушення включають зниження лібідо і потенції, передчасну еякуляцію або її затримку, аноргазмію тощо і визначаються гіперактивацією серотонінергічних рецепторних структур у підкіркових ядрах центральної нервової системи, що регулюють біосинтез і вивільнення статевих гормонів, що призводить до нейромедіаторного та гормонального дисбалансу, який служить основою формування сексуальної дисфункції.

\section{Когнітивна дисфункція}

Порушення когнітивної сфери (ослаблення пам'яті, насамперед оперативної; концентрації уваги, здатності до навчання) $\epsilon$ характерним ускладненням при лікуванні препаратами ТЦА, особливо при тривалому застосуванні [20]. Ризик їх розвитку суттєво зростає у пацієнтів похилого та старечого віку і може розглядатися як предиктор розвитку синдрому помірних когнітивних розладів і навіть хвороби Альцгеймера. Механізми розвитку когнітивних порушень при прийомі ТЦА досить різноманітні і включають перш за все їх холінолітичну дію, а також інгібування біосинтезу факторів нейропластичності, початково ослабленої у пацієнтів із афективними розладами.

\section{Порушення сну}

Як відомо, порушення сну - одна з найбільш характерних ознак депресивних розладів і дистимії $[6,21]$. Це порушення засинання та пробудження, дезорганізація структури сну. Більшість відомих антидепресантів (ТЦА, СІ33С, І33СН) тією чи іншою мірою впливають на структуру сну. Однак для кожного препарату вплив на сон досить специфічний. Наприклад, на початкових стадіях фармакотерапії амітриптилін може прискорювати засинання, при цьому порушуючи структуру сну і викликаючи подальшу денну сонливість, а флуоксетин і венлафаксин - навпаки, ускладнюють засинання, викликаючи «вечірню інсомнію» [22]. Загалом багато представників ТЦА сприяють седації і денній сонливості або посилюють прояви інсомнії і викликають кошмарні сновидіння.

Таким чином, більшість конвенційних антидепресантів чинять негативний вплив на сон, що може нівелювати їх позитивні терапевтичні ефекти і навіть призводити до відмови від подальшого лікування.

Тут дуже коротко перелічені основні побічні ефекти класичних антидепресантів, актуальні для терапевтичної практики. Крім цього, при застосуванні ТЦА можливий розвиток побічних ефектів, пов'язаних з їх холінолітичними й антигістамінними властивостями (седація, головний біль, сухість у роті, запор, затримка сечі, загострення глаукоми), а також ряду неврологічних (судомний синдром) та психічних (психотичні реакції) ускладнень [23]. При тривалому застосуванні СІ33С можливий розвиток ангедонії - синдрому емоційного пригнічення [24], для I33СH (венлафаксину) - слабкість, головний біль, психомоторне збудження, тремор та ін. [25]. Нарешті наявність досить великого потенціалу міжлікарської взаємодії (особливо у препаратів ТЦА та $\mathrm{I33CH)} \mathrm{і} \mathrm{в} \mathrm{результаті} \mathrm{-} \mathrm{ризик} \mathrm{розвитку} \mathrm{несподіваних} \mathrm{побічних}$ ефектів істотно ускладнює застосування класичних антидепресантів у пацієнтів із супутньою патологією, що одержують комбіновану терапію соматотропними та/або нейротропними засобами.

Виходячи з вищезазначеного, слід визнати цілком виправданим інтерес фармакологів і клініцистів до пошуку та впровадження в практику нових альтернативних антидепресантів, що не поступаються за ефективністю згаданим групам лікарських засобів, але переважають їх за критерієм безпеки i, в ряді випадків, за широтою спектра терапевтичного застосування, при цьому здатні «працювати» і у якості тимостабілізатора. Особлива необхідність у згаданих препаратах відмічається, насамперед, при психоемоційних розладах у рамках психосоматичної патології, нейроциркуляторної дистонії, соматоформних больових розладах, стресозалежних патологічних станах («синдром менеджера») та ін., тобто у ситуаціях повсякденної практики сімейного лікаря або невролога. Саме при зазначених розладах відмічається максимальна різноманітність клінічних проявів психоемоційного дисбалансу і водночас зростають вимоги до безпеки інструменту антидепресивної терапії у зв'язку з його частим застосуванням в амбулаторних умовах. 
Одним із таких засобів, що принципово відрізняється від конвенційних препаратів антидепресантів і характеризує іншу стратегію фармакотерапевтичного впливу - нейрометаболічну фармакотерапію, $\epsilon$ інноваційна комбінована вітчизняна дієтична добавка Депріліум ${ }^{\circledast}$, до складу якої входять:

- S-аденозил-L-метіонін (SAM) - 200 мг;

- L-метилфолат - 0,4 мг (еквівалентно 0,4 мг фолієвої кислоти);

- вітамін В 12 (у формі метилкобаламіну) - 0,25 мг.

Одразу слід зазначити, що компоненти комплексу Депріліум ${ }^{\circledast}$ у вітчизняній медицині не асоціюються з фармакотерапією депресії і дистимії, тоді як у зарубіжній практиці вони давно й успішно застосовуються в якості інструментів психофармакологічного впливу $[26,27]$. Особливо важливою вбачається ідеологія підбору даних компонентів у рамках однієї лікарської форми. Усі згадані речовини стимулюють біосинтез біогенних амінів - серотоніну, норадреналіну і дофаміну, але на різних стадіях їх утворення в нервових закінченнях. Як відомо, саме концепція дефіциту біогенних амінів у центральній нервовій системі як ключового фактора розвитку клінічної картини афективних розладів лежить в основі сучасної стратегії лікування депресії. У той самий час усі конвенційні антидепресанти впливають на інші складові реалізації ефектів біогенних амінів - їх зворотне захоплення в синаптичній щілині і зв'язування з постсинаптичними рецепторами.

Таким чином, тільки Депріліум ${ }^{\circledast}$ серед усіх інструментів антидепресивної терапії сприяє безпосередньому впливу на первинну складову нейромедіаторних процесів - біосинтез медіатора в пресинаптичних терміналях моноамінергічних нейронів, що саме по собі забезпечує максимально фізіологічний шлях стимуляції згаданих ефектів. Саме цим визначаються широта ефекту та безпека цього засобу в клінічній практиці.

Дотепер накопичено великий світовий досвід застосування всіх компонентів, які входять до складу дієтичної добавки Депріліум $^{\oplus}$, в лікуванні афективних розладів. SАМ успішно використовується як інструмент монотерапії дистимії та депресії легкого та середнього ступеня тяжкості [28]. У той самий час і SAM, i L-метилфолат, і метилкобаламін $\epsilon$ дуже затребуваними інструментами стратегії аугментації - посилення за їх допомогою дії класичних антидепресантів при недостатній клінічній відповіді або рефрактерності до препаратів CI33C і I33CH, а також з метою зниження дози останніх внаслідок їх поганої переносимості, але при необхідності збереження необхідного рівня ефективності [26, 28, 29].

Таким чином, Депріліум ${ }^{\circledast}$ може бути показаний не тільки в якості інструменту монотерапії, але і послугує своєрідним «рятувальним колом» у досить частих ситуаціях незадовільного результату застосування конвенційних антидепресантів, у тому числі внаслідок розвитку побічних ефектів останніх.

Усі компоненти комплексу Депріліум ${ }^{\circledast}$ характеризуються виключно сприятливими характеристиками безпеки. Незначні побічні ефекти у вигляді диспептичних розладів (нудота, діарея) і шкірних алергічних реакцій незіставні з розглянутими серйозними ускладненнями в рамках терапії класичними антидепресантами і дозволяють говорити про високий рівень безпеки добавки Депріліум ${ }^{\oplus}$ у клінічній практиці. Нарешті простота і зручність її вживання (1-2 капсули на добу терміном до 3 міс) як у монотерапії, так і при стратегії аугментації, а також відсутність необхідності титрування дози дозволяють забезпечити високий ступінь комплаєнсу в процесі терапії та розширити можливості амбулаторного лікування афективних розладів.

\section{Заключення}

У підсумку, проблема безпеки застосування антидепресантів сьогодні виходить на перший план у клінічній психофармакології та фармакотерапії. Включення в повсякденну практику інноваційних засобів з антидепресивними і тимостабілізувальними властивостями дозволяє на тлі збереження ефективності терапії афективних розладів істотно підвищити безпеку лікування відповідно до сучасних світових стандартів.

\section{Список використаної літератури}

1. Марута Н.А. (2001) Современные депрессивные расстройства (клинико-психопатологические особенности, диагностика, терапия). Укр. вісн. психоневрол., 9(4): 79-82.

2. Напрєєнко О.К., Логановський К.М., Сиропятов О.Г. та ін. (2013) Нециркулярні депресії. Софія-А, Київ, 623 с.

3. Купко Н. (2019) Скринінг та діагностика депресії в умовах первинної ланки охорони здоров'я. НейроNews, 9: 24-28.

4. Schatzberg A., DeBattista C. (2015) Manual of Clinical Psychopharmacology (Eight Edition). Washington: Amer. Psychiat. Publ., $687 \mathrm{p}$.

5. Бурчинский С.Г. (2021) Депрессия и тревога у пациентов после перенесенного COVID-19: возможности комбинированной терапии. Журн. неврол. им. Н.Б. Маньковского, 9(1-2): $15-21$.

6. AbadV.C., GuilleminaultC. (2005) Sleep and psychiatry. Dialogues Clin. Neurosci., 7:291-303.

7. Klaser K., Thompson E.J., Nguyen L.H. et al. (2021) Anxiety and depression symptoms after COVID-19 infection: results from the COVID Symptom Study app. MedRxiv. doi 10.1101/2021.07.07/21260137.

8. Bueno-Notivol J., Gracia-Garcia P., Olaya B. et al. (2020) Prevalence of depression during the COVID-19 outbreak: a meta-analysis of community-based studies. Int. J. Clin. Health Psychol. doi:10.1016/j.jjchp.2020.07.007.

9. Свістільник Р.В., ПоліщукВ.А. (2021) Антидепресанти та ризикиз боку серцево-судинної системи. Позитивні і негативні сторони використання в клінічній практиці. Здоров'я України, 19: 75-77.

10. Leonard C.E., Bilker W.B., Newcomb C. et al. (2011) Antidepressants and the risk of sudden cardiac death and ventricular arrhythmia. Pharmacoepidemiol. Drug Saf., 20: 903-913.

11. Emul E., Dalkiran M., Samim S. et al. (2009) The influence of depression and venlafaxine at therapeutic doses on atrial conduction. J. Psychopharmacol., 23: 163-167.

12. Liu L., Fuller M., Behymer T.P. et al. (2020) Selective serotonine reuptake inhibitors and intracerebral hemorrhage risk and outcome. Stroke, 51: 1135-1141.

13. Kivrak Y., Guvenc T.S., Akbulut N. et al. (2014) Accelerated hypertension after venlafaxine usage. Case Rep. Psychiat. doi 10.1155/2014/659715.

14. Wathra R., Mulsand B.H., Thompson L. et al. (2020) Hypertension and orthostatic hypotension with venlafaxine treatment in depresses older adults. J. Psychopharmacol., 34: 1112-1118.

15. Beyazyuz M., Albayrak Y., Eglimez O.B. et al. (2013) Relationship between SSRI and metabolic syndrome abnormalities in patients with generalized anxiety disorder: a prospective study. Psychiat. Investig. 10: 148-154.

16. Chavez-Castillo M., Ortega A., Nava M. et al. (2018) Metabolic risk in depression and treatment with selective serotonine reuptake inhibitors: are the metabolic syndrome and an increase in cardiovascular risk unavoidability? Vessel Plus. doi 10.20517/2574-1209.2018.02.

17. Felger J.C. (2019) Role of inflammation in depression and treatment implications. Handb. Exp. Pharmacol., 250: 255-286.

18. Clayton A.H., Crost H.A., Handiwaba L. (2014) Antidepressants and sexual dysfunction: mechanisms and clinical implications. Postgrad. Med., 126: 91-99.

19. Gregorian R.S., Golden K.A., Bahce A. et al. (2002) Antidepressant-induced sexual dysfunction. Ann. Pharmacother., 36: 1577-1589.

20. Moraros J., Nwankwo C., Patten S.B. et al. (2017) The association of antidepressant drug usage with cognitive impairments or dementia, including Alzheimer's disease: a systematic review and meta-analysis. Depress. Anxiety, 34: 217-226.

21. Бурчинский С.Г. (2012) Нарушения сна при депрессиях: новые возможности антидепрессантов. Укр. неврол. журн., 2: 84-89.

22. Lam R.W. (2006) Sleep disturbances and depression: a challenge for antidepressants. Int. Clin. Psychopharmacol., 21(suppl. 1): S25-S29.

23. Gillman P.K. (2007) Tricyclic antidepressant pharmacology and therapeutic drug interactions updated. Brit. J. Pharmacol., 151: 737-748.

24. Price J., Cole V. (2009) Emotional side-effects of selective serotonin reuptake inhibitots: qualitative study. Brit. J. Psychiat., 195: 211-217.

25. pubmed.ncbi.nlm.nih.gov/27186622/

26. Coppen A., Bollander-Gouaille C. (2005) Treatment of depression: time to consider folic acid and vitamin $B_{12}$. J. Psychopharmacol., 19:59-65.

27. Mischoulon D., Fava M. (2002) Role of S-adenosyl-methionine in the treatment of depression: a review of the evidence. Am. J. Clin. Nutr., 76 (suppl.): 1158S-1161S.

28. De Berardis D., Orsolini A., Serroni N. et al. (2016) A comprehensive review on the efficacy of S-adenosyl-methionine in major depressive disorder. CNS Neurol. Disord. Drug Target, 15: $1-10$.

29. Alpert J.E., Papakostas G., Mischoulon D. et al. (2004) S-adenosyl-methionine (SAMe) as an adjunct for resistant major depressive disorder: an open trail following partial or nonresponse to selective serotonin reuptake inhibitors or venlafaxine. J. Clin. Psychopharmacol., 24: 661-664. 


\section{The problem of safety \\ of pharmacotherapy of affective disorders: new opportunities}

\section{S.G. Burchinsky}

State Institution «D.F. Chebotarev's Institute of Gerontology of the NAMS of Ukraine», Kyiv, Ukraine

Abstract. The article considers the problem of finding effective pharmacotherapy of affective and, first of all, depressive disorders. Today, despite the wide choice of antidepressants and mood-stabilizers of different generations and with different types of action, the effectiveness of all strategies for the treatment of depression often remains

Відомості про автора:
Бурчинський Сергій Георгійович — кандидат медичних наук, завідувач відділу інформа-
ційного аналізу Державної установи «Інститут геронтології імені Д.Ф. Чеботарьова НАМН
України», Київ, Україна.
Адреса для кореспонденції:
Бурчинський Сергій Георгійович
04114, Київ, Вишгородська, 67
E-mail: bsg@geront.kiev.ua

unsatisfactory. It is noted that safety characteristics are a leading factor in the widespread introduction of the drug in clinical practice. The risks of side effects of the main groups of conventional antidepressants (tricyclic antidepressants, selective serotonin reuptake inhibitors, serotonin and norepinephrine reuptake inhibitors) were assessed, including effects on the cardiovascular system, metabolic processes, sexual function, cognition, sleep. The expediency of including in everyday practice innovative drugs with antidepressant and thymostabilizing properties was noted, which allows to significantly improve the safety of treatment in accordance with modern world standards while maintaining the effectiveness of treatment of affective disorders.

Key words: affective disorders, depression, pharmacotherapy, Deprilium ${ }^{\oplus}$.

\section{Information about the author:}

Burchinsky Sergiy G. - Candidate of Medical Sciences, Head of the Department of Information Analysis of State Institution «D.F. Chebotarev's Institute of Gerontology of the NAMS of Ukraine», Kyiv, Ukraine.

Address for correspondence:

Sergiy Burchinsky

04114, Kyiv, Vyshgorodska str., 67

E-mail: bsg@geront.kiev.ua 